\title{
Congenital absence of the portal vein with splenomegaly in a young woman (Case report)
}

\author{
Murnizal Dahlan, Indah Situmorang
}

\begin{abstract}
Abstrak
Agenesis vena porta adalah kelainan yang jarang ditemukan dimana aliran darah vena dari limpa dan usus tidak melalui hepar tetapi mengalir ke aliran sistemik melalui berbagai pintasan. Dilaporkan satu kasus pasien wanita berusia 32 tahun dengan kelainan ini dimana pasien mengalami hematemesis dan melena berulang dan didapati adanya splenomegali dan hipersplenisme. Pada angiografi tidak ditemukan adanya vena porta. Dilakukan tindakan splenektomi untuk menurunkan tekanan pada vena-vena sekitar gaster dan mengkoreksi hipersplenisme. Enam bulan pasca operasi dilakukan endoskopi dengan hasil varises pada esofagus sudah menghilang sedangkan varises pada gaster sudah mengecil. (Med J Indones 2005; 14: 122-7)
\end{abstract}

\begin{abstract}
Congenital Absence of the Portal Vein (CAPV) is a rare anomaly in which the intestinal and splenic venous drainage bypasses the liver and drains into the systemic veins through various venous shunts. We present a case of a 32-year-old woman with this malformation, the patient experienced hematemesis and melena repetitively and had splenomegaly and hypersplenism. The angiography demonstrated absence of portal vein. Splenectomy was performed to reduce the pressure of the veins around stomach and to correct the hypersplenism. In endoscopy examination six months after surgery, the esophageal varices had disappear and the size of gastric varices had decrease. (Med J Indones 2005; 14: 122-7)
\end{abstract}

Keywords: Congenital absence of portal vein, splenomegaly, hypersplenism, hematemesis and melena

Congenital absence of the portal vein (CAPV) is a rare congenital malformation in which the intestinal and splenic venous drainage bypasses the liver and drains into inferior vena cava, renal vein or iliac vein through a congenital portosystemic shunt. ${ }^{1-3}$

The first case of this malformation was reported by Abernethy in 1793 and the last one was documented by Appel et al. in 2003. Only twenty seven cases of CAPV has been reported within that period of time. ${ }^{3,4}$ We report one case of CAPV in a 32-year-old woman with splenomegaly and hypersplenism but with no liver nor cardiac anomalies in which she suffered hematemesis and melena repetitively since the age of 4-year-old.

Department of Surgery, Faculty of Medicine University of Indonesia/Dr. Cipto Mangunkusumo Hospital, Jakarta, Indonesia

\section{Case Report}

A 32-year-old woman admitted to the hospital due to hematemesis and melena. She had the first episode of it on the age of 4-year-old and experienced it again on the age of 14 and 24-year-old. She was admitted to the hospital and had blood transfusion at that moment. Three years ago another episode happened, she was hospitalized and was suspected of suffering liver cirrhosis. She underwent endoscopic injection sclerotherapy 4 times and was suggested to undergo this therapy once in a year but she never done it because of afraid of the procedure. There is no history of alcoholism. She never experienced jaundice, intestinal distention, enlargement of abdomen, swelling of the lower extremity, vomiting, nausea and encephalopathy or lost of consciousness. There is no weight loss and stool discolorization.

On physical examination there is no sign of jaundice nor ascites. The liver is not enlarged but the spleen was enlarged and can be palpated on Schuffner 3. 
Laboratory test showed pancytopenia (Hemoglobin $10,3 \mathrm{~g} / \mathrm{dl}$, leucocyte $3.900 / \mu \mathrm{l}$, thrombocyte $118.000 / \mu \mathrm{l}$ ) and liver function test within normal limits (albumin $4,6 \mathrm{~g} / \mathrm{dl}$, globulin $2,6 \mathrm{~g} / \mathrm{dl}$, direct bilirubin $0,2 \mathrm{mg} / \mathrm{dl}$, indirect bilirubin $0,4 \mathrm{mg} / \mathrm{dl}$ ). Transaminases, alkaline phosphatase and $\gamma \mathrm{GT}$ was normal (SGOT 18U/l, SGPT 7U/l, Alkaline phosphatase 121U/l, and $\gamma$ GT 15U/l). Haemostatic test showed chronic DIC (PT 12,1s; control 11,8s; APTT 25,8s; control 28,1s; fibrinogen $244 \mathrm{mg} / \mathrm{dl}$ and D Dimer 600ng/ml).

Endoscopic examination was performed but injection sclerotherapy could not be done because it could generate bleeding so we planned to do splenectomy. MRI of the abdomen revealed no focal lession in the liver and the biliary system intra and extra hepatic was normal. The spleen was enlarged with homogenous density. Gall bladder, pancreas, kidney and aorta were normal. MRI abdomen concluded splenomegaly and fatty liver (Figure 1).

Transfemoral hepatic arteriography and indirect portography demonstrated dilatation and tourtous of splenic artery, varices of gastric and splenic vein. The intra hepatic part of portal vein can not be visualized nor the extra hepatic. No anomaly on the hepatic artery and its branches (fig. 2 and 3 ).

Based on the angiography the diagnosis of CAPV was made. We performed laparotomy and found enlargement of the spleen with no abnormality on the liver. Veins around the stomach were dilated. Splenectomy was done due to hypersplenism.

Histopathology examination of the spleen showed congestion and enlargement of the red pulp, resembled hypersplenism and no sign of malignancy. The patient was discharge 5 days after surgery in good condition.

Six months after the operation patient had no complaints and endoscopy was performed to evaluate the esophageal and gastric varices. The esophageal varices had disappear and the size of gastric varices had decrease.
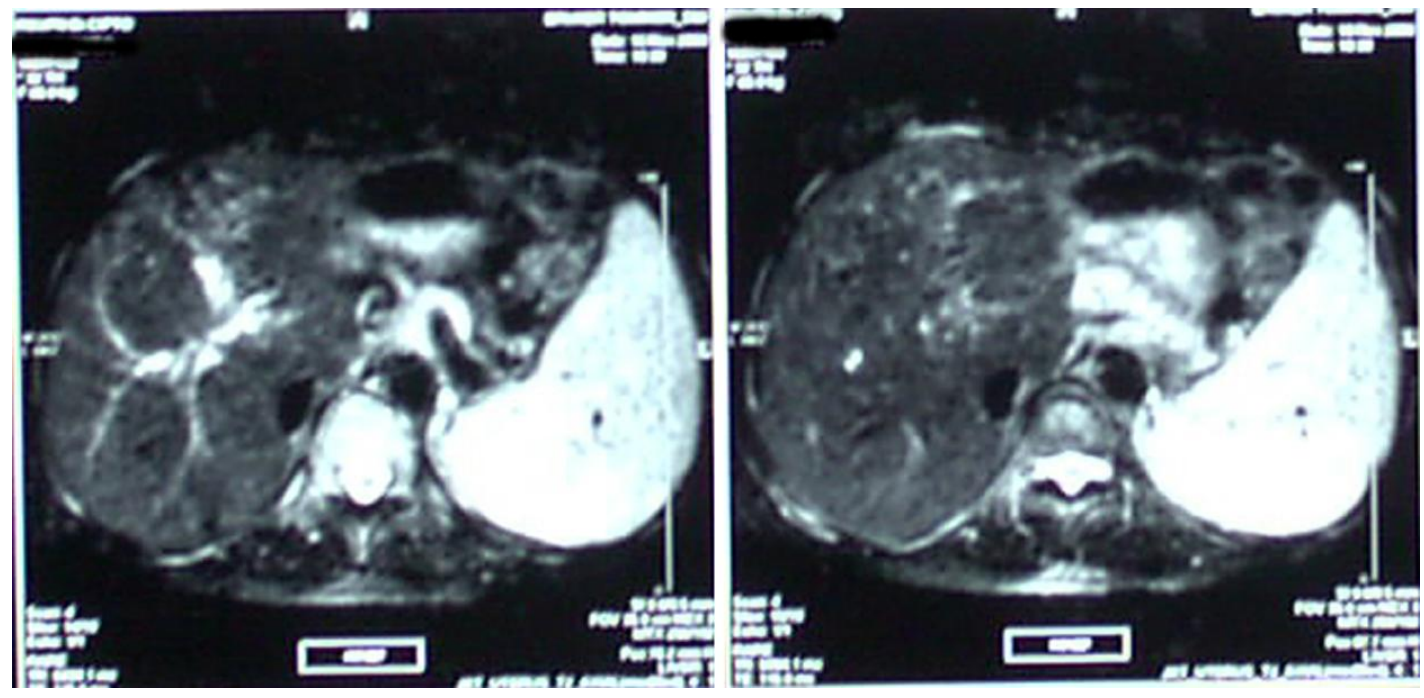

Figure 1. MRI abdomen showing splenomegaly and fatty liver 

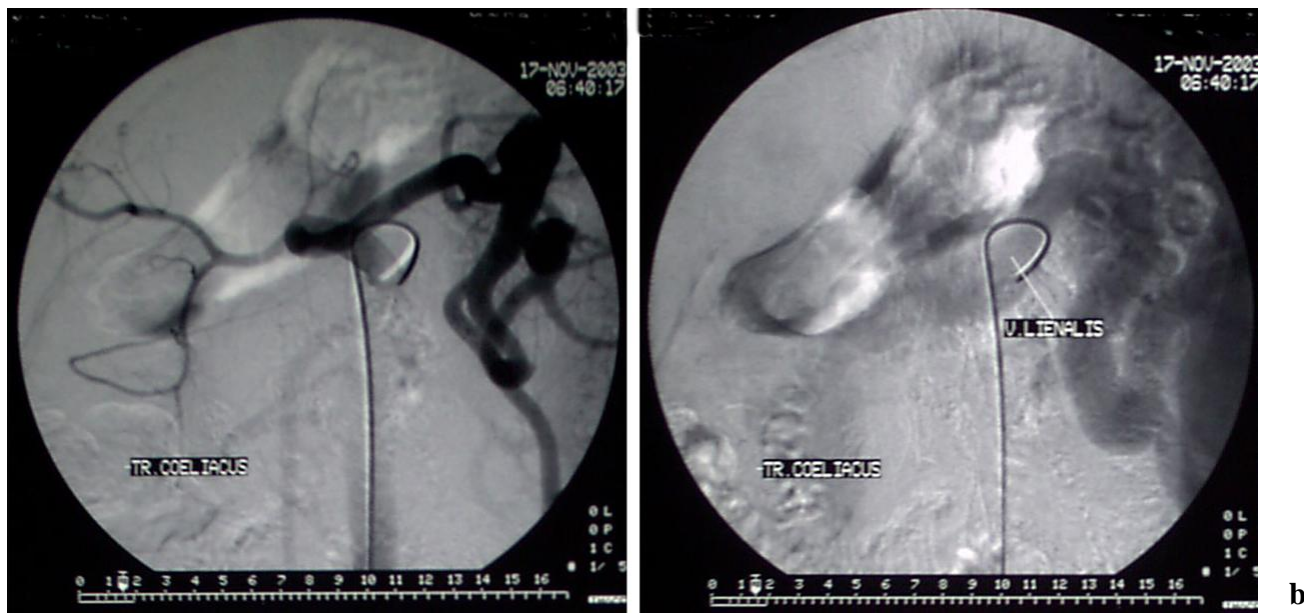

Figure 2. $\boldsymbol{a}$ The arterial phase of celiac angiography showed dilatation of splenic artery. $\boldsymbol{b}$ The venous phase of celiac angiography showed varices of splenic vein, the portal vein was absence until the end of venous phase.

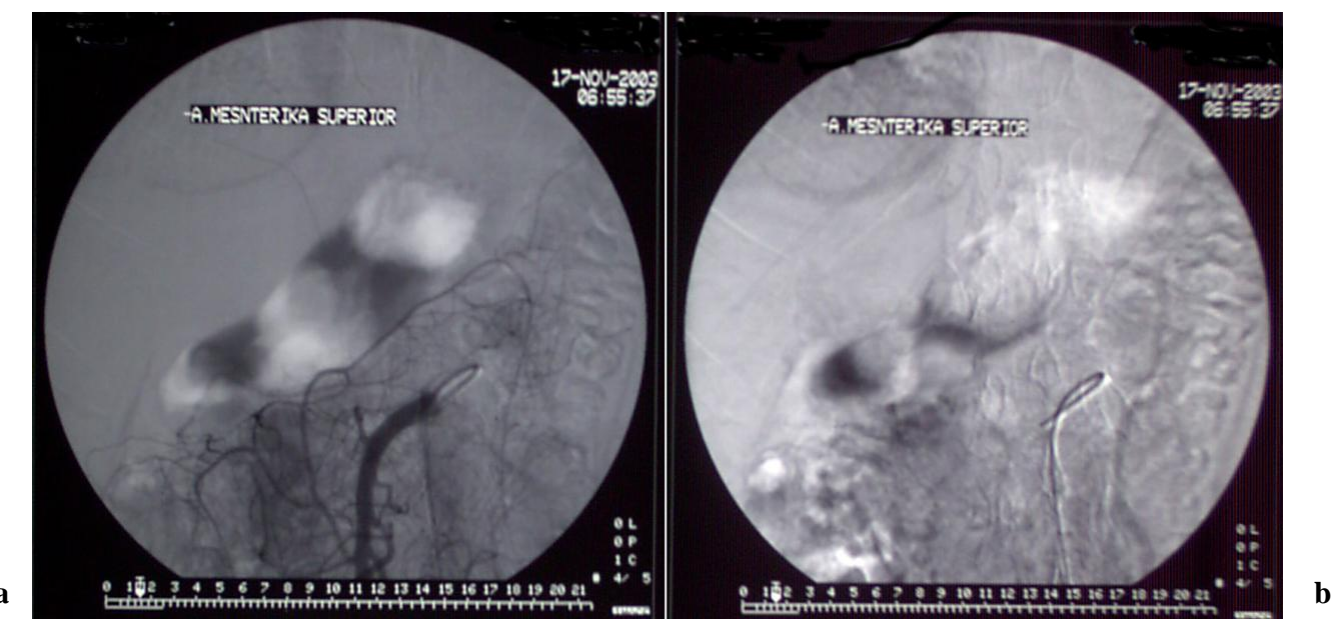

Figure 3. a Angiography of the superior meseneteric artery. $\boldsymbol{b}$ The venous phase of superior mesenteric angiography did not show the portal vein.

\section{DISCUSSION}

Embryologically, the portal vein formed in the 5-10 weeks of gestation, it derives from selective involution and the persistence of the vitelline venous system. $^{1-3,5}$ Abnormal patterns of involution and persistence may result in a preduodenal, prebiliary or duplicated portal vein, and excessive involution may result in absence of the portal vein. ${ }^{2,5}$ The complex development of the vena cava and its close relation to development of the vitelline veins likely explain the occurrence of the rare congenital extrahepatic portosystemic anastomoses. $^{2}$

Congenital absence of the portal vein was first reported by Abernethy in 1793.,.$^{3,11}$ Morgan and Superina in 1994 proposed a classification of portosystemic anomalies (Table 1). ${ }^{1}$

There is a clear clinical distinction between patients with the type I and type II shunts. In type I shunts, the patients are typically young at the time of presentation. 
There usually is little encephalopathy, despite the pressence of high ammonemia levels. Often there are other anomalies including cardiac malformations and hepatic tumors. In the type II shunt, which is most often acquired, the patients typically present at middle or late-middle age. The initial symptoms often are encephalopathy with a high serum amonia level of unknown cause and a vascular anomaly, which is discovered after various investigations. ${ }^{1-3,6,7}$ Type II shunt are often secondary to cirrhosis, but congenital shunts have been reported. ${ }^{1,8,9}$

Table 1. Classification system for Portosystemic Anomalies ${ }^{1}$

Type I Liver not perfused with portal blood - total shunt (eg. CAPV)

Ia Superior mesenteric vein and splenic vein do not join to form confluence

Ib Superior mesenteric vein and splenic vein join to form confluence

Type II Liver perfused with portal blood - partial shunt (eg. Portal-hepatic anastomoses)

IIa congenital

IIb acquired

Within the period of 1793-2003, 27 cases of type I portosystemic anomalies have been reported, 14 patients were subtype $\mathrm{Ib}$ and there were only 3 subtype Ia patients. The subtype of 10 other cases were not clear. ${ }^{3,4}$ The CAPV in our patient was a type I shunt but the subtype can not be defined because the presence of confluence of the superior mesenteric vein and splenic vein can not be determined during angiography.

CAPV predominantly found in female and in 24 cases the diagnosis was made before the age of 18-year-old (Tabel 2). ${ }^{3,10}$ Cardiac and liver malformations are frequently observed in patients with CAPV. ${ }^{1-10}$ Typical additional liver diseases are focal nodular hyperplasia, hepatocellular adenoma, hepatocellular carcinoma and biliary atresia. Cardiac anomalies that may occur are patent ductal arteriosus, patent foramen ovale, ventricular septum defect and atrial septum defect. ${ }^{4,6,10,11}$

Our patient experienced hematemesis and melena for the first time at the age 4-year-old. Since then the symptom repeated but she never had encephalopathy nor lost of consciousness. Encephalopathy rarely occurred in CAPV, only 2 CAPV cases with portosystemic encephalopathy were reported, ${ }^{12,13}$ and 1 patient with subclinical encephalopathy had mild tremor as the symptom. ${ }^{14}$

Table 2. Cases of congenital abence of portal vein (CAPV) ${ }^{3,4}$

\begin{tabular}{|c|c|c|c|c|}
\hline Authors (year) & Age & Sex & $\begin{array}{c}\text { Subtype of } \\
\text { CAPV }\end{array}$ & Drainage site \\
\hline Abernethy (1793) & $10 \mathrm{y}$ & $\mathrm{F}$ & $\mathrm{Ib}$ & Suprahepatic IVC \\
\hline Kiernan (1833) & $13 y$ & $\mathrm{~F}$ & - & IVC \\
\hline Hellweg (1954) & $5 \mathrm{~m}$ & $\mathrm{~F}$ & $\mathrm{Ib}$ & Suprahepatic IVC \\
\hline Olling (1974) & $50 \mathrm{y}$ & $\mathrm{F}$ & $\mathrm{Ib}$ & Suprahepatic IVC \\
\hline Marois (1979) & $4 y$ & $\mathrm{~F}$ & $\mathrm{Ib}$ & Left renal vein \\
\hline $\begin{array}{l}\text { Morse (1986) dan } \\
\text { Barton (1989) }\end{array}$ & $8 y$ & $\mathrm{~F}$ & Ia & $\begin{array}{l}\text { Suprahepatic IVC } \\
\text { (SMV), Left renal } \\
\text { vein (SV) }\end{array}$ \\
\hline Okuda (1988) & $17 y$ & $\mathrm{~F}$ & $\mathrm{Ib}$ & Left renal vein \\
\hline Joyce (1988) & $10 y$ & F & $\mathrm{Ib}$ & Suprarenal IVC \\
\hline Nakasaki (1989) & $14 y$ & $\mathrm{~F}$ & Ia & Left renal vein \\
\hline Bellah (1989) & $16 \mathrm{~d}$ & $\mathrm{M}$ & - & Suprahepatic IVC \\
\hline Woodle (1990) & $10 y$ & $\mathrm{~F}$ & Ia & IVC (SMV) \\
\hline Matsuoka (1992) & $22 \mathrm{y}$ & $\mathrm{F}$ & $\mathrm{Ib}$ & Suprarenal IVC \\
\hline Morgan (1994) & $9 w$ & $\mathrm{~F}$ & $\mathrm{Ib}$ & IVC \\
\hline Laverdiere (1995) & $\begin{array}{l}8 \mathrm{w} \\
1 \mathrm{~d}\end{array}$ & $\begin{array}{l}F \\
F\end{array}$ & $\begin{array}{c}\mathrm{Ib} \\
-\end{array}$ & $\begin{array}{l}\text { The right atrium } \\
\text { Left renal vein } \\
\text { (SMV) }\end{array}$ \\
\hline Howard (1997) & $9 w$ & $\mathrm{~F}$ & - & Azygos veins \\
\hline Guariso (1998) & $10 y$ & $\mathrm{~F}$ & - & Suprahepatic IVC \\
\hline Motoori (1997) & $18 \mathrm{y}$ & $\mathrm{F}$ & $\mathrm{Ib}$ & Suprahepatic IVC \\
\hline Kim (1998) & $8 \mathrm{~m}$ & $\mathrm{~F}$ & - & IVC \\
\hline Kohda (1999) & $11 \mathrm{y}$ & M & $\mathrm{Ib}$ & Suprarenal IVC \\
\hline Wakamoto (1999) & $6 y$ & $\mathrm{~F}$ & - & - \\
\hline Massin (1999) & $5 y$ & $\mathrm{~F}$ & $\mathrm{Ib}$ & Right \\
\hline \multirow[t]{2}{*}{ Grazioli (2000) } & $10 y$ & M & $\mathrm{Ib}$ & $\begin{array}{l}\text { Intrahepatic } \\
\text { portion of IVC }\end{array}$ \\
\hline & $14 y$ & $\mathrm{~F}$ & - & $\begin{array}{l}\text { Right internal } \\
\text { iliac vein }\end{array}$ \\
\hline Shinkai (2000) & $1,8 \mathrm{y}$ & M & - & Left renal vein \\
\hline Tanaka (2001) & $16 y$ & $\mathrm{~F}$ & $\mathrm{Ib}$ & Suprahepatic IVC \\
\hline Appel (2003) & $33 y$ & $\mathrm{~F}$ & - & Azygos veins \\
\hline
\end{tabular}

D, days; IVC, inferior vena cava; m, months; SMV, superior mesenteric vein; SV, splenic vein; w, weeks; y, years 
In our case the patient had splenomegaly, hypersplenism and esophageal varices. Appel et al. reported a CAVP case in a 33-year-old woman with splenomegaly and hypersplenism with no esophageal varices documented on the abdominal CT scan. ${ }^{4}$

Liver chemistry may be slightly altered in cases of CAPV as reported in some literatures, but in our case the liver function test and transaminases are within normal range. This is similar with the report from Laverdiere et al. ${ }^{15}$

Our patient with a history of variceal bleeding was suspected of suffering hepatic cirrhosis, but the laboratory findings and abdominal MRI unlikely support that diagnosis. The condition of noncirrhotic portal hypertension with the possibility of anomaly of the portal vein were the probable cause of that symptom. We performed angiography to evaluate the vessel and confirm the diagnosis. Hepatic angiography and indirect portography could not identify the pressence of the extra hepatic nor the intra hepatic portal vein, the systemic shunt could not be identified either.

In most previous cases, a common trunk formed by the joined superior mesenteric vein and splenic vein draining directly into the inferior vena cava was the most frequent type of systemic shunt ${ }^{4,11}$ followed by drainage through the left renal vein. ${ }^{4}$

Ultrasonography with echo-color Doppler is usually used as a first method in diagnosing abnormality of portal vein. Though this method can not visualize the portal vein or its main branch, it does show the portocaval shunt as an abnormal pattern on the echocolor Doppler. Further examination can then be planned. CT Scan or MRI can confirm the absence of portal vein and they both can visualize the portosystemic shunt. ${ }^{2}$ MR angiography offers the practical advantage of demonstrating the patency and flow direction of the portal vein, and the pressence and extent of the portal venous collaterals in any part of the body. MR angiography has little interference from such body condition as the presence of bowel gas. 5

MR angiography could not be done in our case due to unavailability of the device, thus the drainage site of the superior mesenteric vein and splenic vein could not be confirmed. Based on the history of no encephalopathy nor lost of consciousness due to elevation of the ammonia level in the blood, we hypothesized there could be a drainage system into the caval vein or into intrahepatic vessels.

There is no strict protocol in the treatment of CAPV. The therapy is adjusted according the symptom, the type of congenital systemic shunt and the pressence of other congenital anomaly. Appel et al. reported a case that almost similar like ours, CAPV in a young woman with hypersplenism and splenomegaly but with no hematemesis and melena. In that case the mesenteric blood was drained cranially into the azygos system through extensive paragastric and parasplenic collaterals. Surgical procedure for the splenomegaly was not carry out on that case. ${ }^{4}$ In our case, splenectomy was indicated due to hypersplenism and esophageal varices which injection of sclerosing agent could not be done. Thus, the pressure in the veins around the stomach could be decreased and the varix would disappear.

In the future, if the pressure in the mesenteric veins remains high or the number of the collateral not sufficient, there is still a possibility that our patient will suffer variceal bleeding again. On that condition, we must assess the condition of the vessels by MR angiography then planned further treatment. ${ }^{16}$

Several studies have recommended major operations for gastric varices such as portosystemic shunt, ${ }^{17}$ distal splenorenal shunt18 and esophageal transection.19,20 Gastric devascularization and splenectomy can be done for treating esophageal varices. The extent of devascularization included the lower 5 to $10 \mathrm{~cm}$ of the esophagus, a lesser curvature to the level of the incisura angularis, and a greater curvature of the stomach to the level adjacent to the incisura angularis. ${ }^{20}$ This procedure may also be feasible for gastric varices, because devascularization can directly eradicate blood flow into the gastric wall. ${ }^{20,21}$

The options of surgical procedure that can be performed in our patient if the symptom occur again are shunt surgery such as mesocaval H-graft shunt, coronary-caval shunt (Inokuchi shunt) or gastric devascularization.

Based on the findings in the literature, the shortterm prognosis of patients with CAPV depends on the presence of heart disease in the newborn and the presence of liver disease, whereas the longterm prognosis is controlled by the presence of metabolic disease such as hyperammonemia. ${ }^{6}$ There is little information in the literature on the outcome of 
patients with CAPV, further longterm follow-up is necessary.

\section{Acknowledgement}

The author would like to thank dr. Errol Hutagalung, Sp.B, Sp.OT for reviewing this manuscript.

\section{REFERENCES}

1. Morgan G, Superina R. Congenital absence of the portal vein: two cases and a proposed classification system for portosystemic vascular anomalies. J Pediatr Surg 1994; 29:1239-41.

2. Niwa T, Aida N, Tachibana K, Shinkai M, Ohhama Y, Fujita K, et al. Congenital absence of the portal vein: clinical and radiologic findings. J Comput Assist Tomogr 2002;26:681-6.

3. Tanaka Y, Takayanagi M, Shiratori Y, Imai Y, Obi S, Tateishi R, et al. Congenital absence of portal vein with multiple hyperplastic nodular lesions in the liver. J Gastroenterol 2003;38:288-94.

4. Appel H, Loddenkemper C, Schirmacher P, Dienes HP, Sieper J, Rudwaleit M. Congenital absence of the portalvein with splenomegaly and hypersplenism in a young woman. Digestion 2003;67:105-10.

5. Arana E, Marti-Bonmati L, Martinez V, Hoyos M, Montes H. Portal vein absence and nodular regenerative hyperplasia of the liver with giant inferior mesenteric vein. Abdom Imaging 1997;22:506-8.

6. Kinjo $\mathrm{T}$, Aoki $\mathrm{H}$, Sunagawa $\mathrm{H}$, Kinjo S, Muto Y. Congenital absence of the portal vein associated with focal nodular hyperplasia of the liver and congenital choledocal cyst: a case report. J Pediatr Surg 2001;36:622-5.

7. Kohda E, Saeki M, Nakano M, Masaki H, Ogawa K, Nirasawa M, et al. Congenital absence of the portal vein in a boy. Pediatr Radiol 1999;29:235-7.

8. Lewis AM, Aquino NM: Congenital portohepatic vein fistula that resolved spontaneusly in a neonate. AJR 1992;159:837-8

9. Chagnon SF, Vallee CA, Barge J. Aneurysmal portohepatic venous fistula: report of two cases. Radiology 1986; 159:693-5.
10. Motoori S, Shinozaki M, Goto N, Kondo F. Case report: congenital absence of the portal vein associated with nodular hyperplasia in the liver. J Gastroenterol Hepatol 1997;12:639-43

11. Grazioli L, Alberti D, Olivetti L, Rigamonti W, Codazzi F, Matricardi L, et al. Congenital absence of portal vein with nodular regenerative hyperplasia of the liver. Eur Radiol 2000;10:820-5.

12. Woodle ES, Thistlethwaite JR, Emond JC, Whitington PF, Vogelbach P, Yousefzadeh DK, et al. Successful hepatic transplantation in congenital absence of recipient portal vein. Surgery 1990;107:475-9.

13. Shinkai M, Ohhama Y, Nishi T, Tanaka Y, Takemiya S, Tanaka K, et al. Living related partial liver tranplantation for hyperammonemia due to congenital absence of the portal vein. Transplant Proc 2000;32:2184.

14. Wakamoto $\mathrm{H}$, Manabe $\mathrm{K}$, Kobayashi $\mathrm{H}$, Hayashi $\mathrm{M}$. Subclinical portal-systemic encephalopathy in a child with congenital absence of the portal vein. Brain Dev 1999;9:522-5.

15. Laverdiere JT, Laor T, Benacerraf B. Congenital absence of the portal vein: case report and MR demonstration. Pediatr Radiol 1995;25:52-3.

16. Wolff M, Hirner A. Current state of portosystemic shunt surgery. Langenbecks Arch Surg 2003;388:141-9.

17. Sarfeh IJ, Rypins EB, Conroy RM, Mason GR. Portocaval H-graft: relationships of shunt diameter, portal flow patterns and encephalopathy. Ann Surg 1983;197:422-6.

18. Warren WD, Henderson JM, Millikan WJ. Distal splenorenal shunt versus endoscopic sclerotherapy for long term management of variceal bleeding. Preliminiary report of a prospective, randomized trial. Ann Surg 1986;203:454-62.

19. Sugiura M, Futagawa S. A new technique for reating esophageal varices. J Thorac Cardiovasc Surg 1973; 66:677-85.

20. Tomikawa M, Hashizume M, Saku M, Tanoue K, Ohta M, Sugimachi K. Effectiveness of gastric devascularization and splenectomy for patients with gastric varices. J Am Coll Surg 2000;191:498-503.

21. Jin G, Rikkers LF. Transabdominal esophagogastric devascularization as treatment for variceal hemorrhage. Surgery 1996;120:641-9. 